\title{
Internal Flow Effects on Isotropic Confined Sand-Clay Mixtures
}

\author{
D. MAROT, F. BENDAHMANE, F. ROSQUOET, AND A. ALEXIS \\ Institut de Recherche en Génie Civil et Mécanique GeM, Université de Nantes, \\ IUT de Saint-Nazaire, France
}

\begin{abstract}
Under the effect of internal flows, a liner can undergo a washing out of particles, which modifies the particle size distribution and affects hydraulic, chemical and mechanical characteristics. This paper discusses the effects of internal flows on sand/kaolin mixture, in terms of rate of erosion and modification of the hydraulic conductivity. A parametric study is conducted with a specific device that consists of three modified triaxial cells. These cells allow isotropically consolidating and confining specimens, they prevent a parasitic flow and survey large deformations of specimen. The tests reveal that suffusion of clay is accompanied by a clogging in the specimen that induces a drop in hydraulic conductivity. For high gradients the erosion of clay is accompanied by the backward erosion of sand and finally the specimen collapses. The erosion rate then depends on the values of the different parameters considered (hydraulic gradient, clay content and filter pore opening size).
\end{abstract}

Keywords Backward erosion, hydraulic conductivity, internal erosion, rate of erosion, sand-clay mixture, suffusion,

\section{Background}

Sand-clay mixtures are commonly used as liner materials and as core materials in earth structures. Within these structures, internal seepage flows can generate the stripping and transport of some particles. This migration of particles due to hydraulic interflows, named internal erosion, can modify hydraulic and mechanical structural properties. The material conductivity, for instance, undergoes some sharp changes, which cause losses of tightness or interstitial over pressures. Therefore, the design of the earth structures has to take into account the internal erosion effects on hydraulic conductivity.

Internal erosion mechanisms are complex and involve many parameters, coupled or not. Previous laboratory test campaigns (Monnet, 1998; Skempton and Brogan, 1994) identify the mechanisms responsible for the migration of the particles as either suffusion or piping, depending on the interpretation. Suffusion is characterized by an internal redistribution of the fine particles within the soil and can be accompanied by the decrease of the conductivity. Piping, on the other hand, is induced by a backward erosion of particles from the soil downstream and along the upstream line towards an outside environment until forming

Address correspondence to Didier Marot, Associate Professor, Institut de Recherche en Génie Civil et Mécanique GeM, Université de Nantes, BP 420, F-44606 Saint-Nazare cedex, France, E-mail: didier.marot@univ-nantes.fr 
a continuous pipe. The grain size distribution then varies according to the conductivity increase. Piping initiation is difficult to detect and contrary to suffusion it evolves very quickly.

Many parameters (porosity, grain size, confining pressure, hydraulic gradient) influence internal erosion behavior. Different criteria to assess the initiation and development of internal erosion are proposed in the literature (Kenney and Lau, 1985; Khilar et al., 1985). They mostly rest on the material particle size analysis or on the estimation of the erosion critical hydraulic gradient.

On the assumption that bigger grains can hinder the erosion of smaller grains, a method based on the shape of the coarse or the fine low-content grading curve has been developed (Kenney and Lau, 1985) and has been validated for both up and down flows (Monnet, 1998; Skempton and Brogan, 1994). Porosity and soil confinement, however, are not considered in the granulometric approach.

To characterize internal erosion initiation, many authors have developed some expressions of the critical hydraulic gradient. Some of these expressions are strongly dependent on the specific configuration studied and, therefore, cannot be applied generally. Regarding cohesive soils (Khilar et al., 1985), the erosion critical gradient is expressed as a function of the hydraulic shear stress $\tau$ (shear stress generated by flows within the soil porous system), of the intrinsic permeability $K$ and of the porosity n. The main difficulty, when using this model, lies in the determination of $\tau$, dependent upon both clay mineralogy and interstitial fluid properties (Arulanandan and Perry, 1983). For example, to characterize internal erosion initiation, Reddi et al. (2000) propose to model the soil using a cylindrical pipeline network and develop an expression of the shear stress $\tau$ for cohesive soils:

$$
\tau=1.414\left(\frac{\Delta P}{\Delta L}\right) \sqrt{\frac{K}{n}}
$$

with $\Delta P / \Delta L$, the pressure gradient $\left(\mathrm{kN} / \mathrm{m}^{3}\right) ; K$, the intrinsic permeability $\left(\mathrm{m}^{2}\right)$ and $\mathrm{n}$, the porosity.

The many parameters affecting the different phenomena, as well as their evolutive features emphasize the importance of taking suiting experimental precautions.

The present paper reports a study conducted at the Institut de Recherche en Génie Civil et Mécanique (GeM, Saint-Nazaire, France) to provide new data on the effects of internal erosion on sand/clay specimens.

\section{Experimental Device}

\section{Device Description}

Internal erosion tests are realized using a new experimental device (Figure 1). It consists of three identical triaxial cells that are modified and coupled with two pressure/volume controllers (GDS), placed in a temperature-controlled room $\left(20 \pm 1^{\circ} \mathrm{C}\right)$. This device makes it possible to consolidate the samples under isotropic stress, to control the confinement during the tests and to measure any sample volume changes.

The triaxial cells have been modified in order to:

- let the flow come through the specimens while limiting head losses;

- prevent the eroded particles from clogging the draining system. 


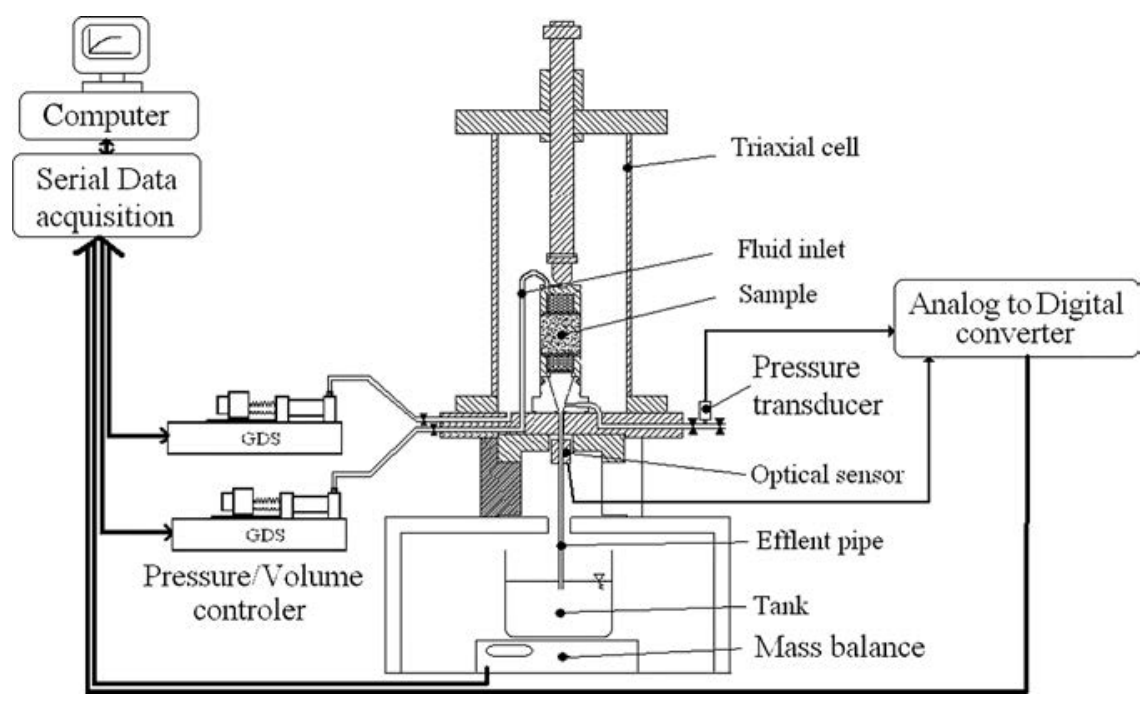

Figure 1. Schematic representation of one of the experimental triaxial cells equipped with the two GDS controllers, effluent weight measurement and optical sensor mechanism.

The injection head consists of a glass sphere (diameter: $5 \mathrm{~mm}$ ) layer with a thickness of $22 \mathrm{~mm}$ to diffuse the fluid on the sample uniformly. At the bottom of the sample, the funnel-shaped draining system is specially designed to avoid clogging or the formation of a layer of particles within the system. This draining system makes it possible to use different filters, which can be either rigid or made of geotextiles with openings ranging between $0.001 \mathrm{~mm}$ and $8 \mathrm{~mm}$ and a maximum thickness of $17 \mathrm{~mm}$ (Figure 2).

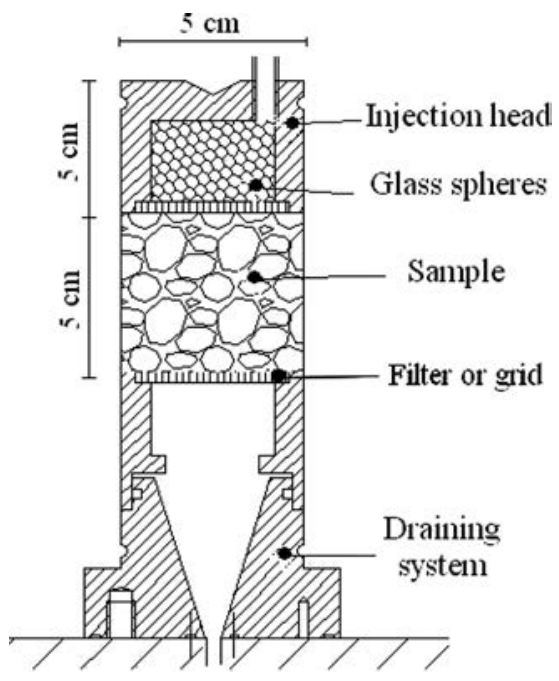

Figure 2. Details of the test piece with its injection head and the draining system. 


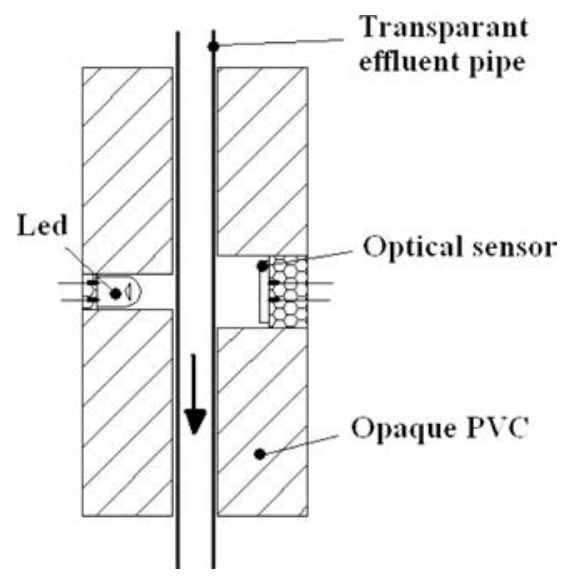

Figure 3. Details of the optical sensor placed on the transparent effluent pipe.

A GDS (Geotechnical Digital System) is used to inject up to $200 \mathrm{~cm}^{3}$ of statically or dynamically pressurized fluid (maximum pressure: $600 \mathrm{kPa}$ ) with an accuracy of $0.001 \mathrm{~cm}^{3}$ and a resolution of $1 \mathrm{kPa}$.

In order to detect the internal erosion initiation time and carry out real-time measurements of the eroded grain quantity, an optical sensor has been developed (Figure 3).

Placed on the transparent pipe connecting the triaxial cell to the effluent tank, it measures the transparency of the fluid coming through the pipe. A preliminary calibration on the suspensions of kaolin makes it possible to establish a relationship between transparency and concentration.

The mass of the outlet effluents, under a constant hydraulic gradient, is obtained using a weighing machine (accuracy: $0.1 \mathrm{~g}$ ). A computer operates the acquisition of data automatically every three seconds. The mass of the eroded material is obtained by computing the difference between the mass of inlet water and the mass of outlet effluent.

\section{Specimen Making}

The cohesive soil specimens are recreated using a mechanical mixture of Loire sand and two types of clay (kaolin for the parametric study and bentonite for the validation test). Two different test specimens are produced, some with a $10 \%$ kaolin content and others with a $30 \%$ kaolin content (in weight). The kaolin is marketed by Prolabo (Strasbourg, France) and its sedimentation analysis indicates that $10 \%$ of the clay particles are $<0.8 \mu \mathrm{m}$ and that the remaining $90 \%$ is $>8 \mu \mathrm{m}$. The Loire sand grain size distribution ranges between $80 \mu \mathrm{m}$ and $2 \mathrm{~mm}$ (Figure 4).

The repeatability of the production is guaranteed by the following procedure:

First, the sand is mixed (mixing machine, vertical axis of rotation, $145 \mathrm{rpm}$ ) during three minutes with a water content of $8 \%$. While mixing continues, powder clay is progressively added and mixing is then carried on for some additional 10 minutes. This method has been validated through confirmation of the size distribution homogeneity achieved after mixing. The installation of the specimen inside the cell requires preliminary forming using a $50 \mathrm{~mm}$ diameter and $50 \mathrm{~mm}$ high mold under the action of two pistons until the required dry density is reached (Bendahmane, 2005). 


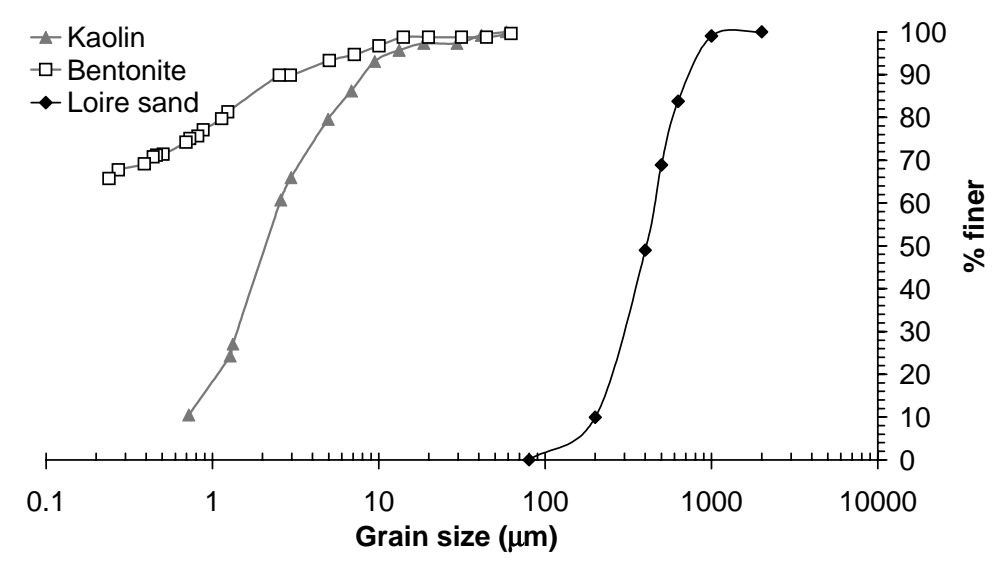

Figure 4. Grain size distributions for the Loire sand, the kaolin used for the erosion tests, and the bentonite used for the conductivity measurements.

Second, the specimen is saturated with distilled water after application of a light confinement pressure to prevent any parasitic flow between the sample and the membrane and any swell of the sample. The water is introduced from the bottom of the specimen in order to prevent the trapping of air bubbles. The saturation rate is reached sufficiently slowly (saturation time of 24 hours) to prevent small particles from migrating.

Third, the cohesive specimen is consolidated at $200 \mathrm{kPa}$ during 24 hours. This isotropic confining pressure is applied to represent the earth pressure. The pressure of confinement increases in stages in conformity with Standard Afnor NFP 94-074. Excess pore pressure measurements are used to control the good quality of the specimen consolidation. The confinement pressure is then decreased by half to avoid the material further consolidation because of the inflow.

\section{Validation Tests (Conductivity Measurements)}

The new experimental device is validated by carrying out conductivity measurements on a sand-bentonite reconstituted material according to the experiment conditions defined by Kenney et al. (1992). The bentonite is a Prolabo of montmorillonite type, whose sedimentation analysis shows that $65 \%$ of the particles are smaller than $0.2 \mu \mathrm{m}$ and none are bigger than $80 \mu \mathrm{m}$ (Figure 4). The chemical composition (chemical analysis by X-ray fluorescence, provided by the supplier) is $\mathrm{Al}_{2} \mathrm{O}_{3}: 15 \%, \mathrm{CaO}: 2 \%, \mathrm{Fe}_{2} \mathrm{O}_{3}: 1 \%, \mathrm{MgO}: 4 \%, \mathrm{SiO}_{2}$ : $60 \%$, Alkalis and other: $3 \%$, Loss on ignition: $15 \%$.

According to their experimental conditions, which consist of an $8 \%$ sand/bentonite weight ratio, a $60 \mathrm{kPa}$ axial stress of consolidation in a rigid cell permeameter (the cylindrical test pieces are $50 \mathrm{~cm}^{2}$ for the section and 25 to $30 \mathrm{~mm}$ for the height) and a $15 \mathrm{~m} / \mathrm{m}$ hydraulic gradient, the hydraulic conductivity $(k)$ measured by Kenney et al. (1992) ranges between $2.1 \times 10^{-10}$ and $2.2 \times 10^{-10} \mathrm{~m} / \mathrm{s}$. The specimens used for the validation here have been reconstituted in the same sand/bentonite proportions and with an identical sand size distribution. The conductivity measured on three different specimens with the new device is $2.3 \times 10^{-10} \mathrm{~m} / \mathrm{s}, 2.4 \times 10^{-10} \mathrm{~m} / \mathrm{s}$ and $2.6 \times 10^{-10} \mathrm{~m} / \mathrm{s}$, respectively. The good agreement between the conductivity results achieved experimentally using the modified triaxial cell 
and the values found in the literature demonstrates the validity of the experimental procedure discussed here.

\section{Test Procedure and Parametric Study}

The internal erosion tests are conducted to examine three parameters (kaolin content, hydraulic gradient and filter opening size). The tests are performed on specimens with $10 \%$ and $30 \%$ kaolin contents, respectively. The chosen $8 \%$ water content corresponds to a dry unit weight of $17 \mathrm{kN} / \mathrm{m}^{3}$. The isotropic confinement pressure is kept steady at 200 $\mathrm{kPa}$, which is equivalent to the earth pressure found $12 \mathrm{~m}$ deep. The hydraulic gradient is constant during each test, from $2 \mathrm{~m} / \mathrm{m}$ to $27 \mathrm{~m} / \mathrm{m}$ for specimens with a $10 \%$ kaolin content and from $32 \mathrm{~m} / \mathrm{m}$ to $168 \mathrm{~m} / \mathrm{m}$ for specimens with a $30 \%$ kaolin content (Table 1). A $4 \mathrm{~mm}$ pore opening grid is placed under the specimen (Figure 2) to survey the migration of all the particles (sand and clay minerals). To examine the erosion of clay particles only, a woven filter with a $0.08 \mathrm{~mm}$ pore opening is placed at the top of the grid.

The continuous measurement of the solid concentration of the effluent allows for the calculation of the erosion rate, $q_{s}(t)$, defined as the eroded mass per second and also called the solid flow rate:

$$
q_{s}(t)=C(t) q_{w}(t)
$$

with $C(t)$, the concentration (in $\mathrm{mg} / \mathrm{cm}^{3}$ ) measured by the optical sensor and $q_{w}(t)$, the fluid flow rate (in $\mathrm{cm}^{3} / \mathrm{s}$ ) measured by the injection pressure volume controller.

Table 1

Main characteristics of the tests

\begin{tabular}{rcccc}
\hline Tests & $\begin{array}{c}\text { Specimen kaolin } \\
\text { content }(\%)\end{array}$ & $\begin{array}{c}\text { Specimen initial } \\
\text { porosity }(\%)\end{array}$ & $\begin{array}{c}\text { Filter opening } \\
\text { size }(\mathrm{mm})\end{array}$ & $\begin{array}{c}\text { Hydraulic } \\
\text { gradient i }(\mathrm{m} / \mathrm{m})\end{array}$ \\
\hline 1 & 10 & 33 & 0.08 & 4 \\
2 & 10 & 33 & 0.08 & 27 \\
3 & 10 & 33 & 4 & 2 \\
4 & 10 & 33 & 4 & 4 \\
5 & 10 & 33 & 4 & 8 \\
6 & 10 & 33 & 4 & 12 \\
7 & 10 & 33 & 4 & 22 \\
8 & 10 & 33 & 4 & 27 \\
9 & 30 & 30 & 0.08 & 32 \\
10 & 30 & 30 & 0.08 & 110 \\
11 & 30 & 30 & 4 & 44 \\
12 & 30 & 30 & 4 & 48 \\
13 & 30 & 30 & 4 & 168 \\
14 & 30 & 30 & 4 & 92 \\
\hline
\end{tabular}




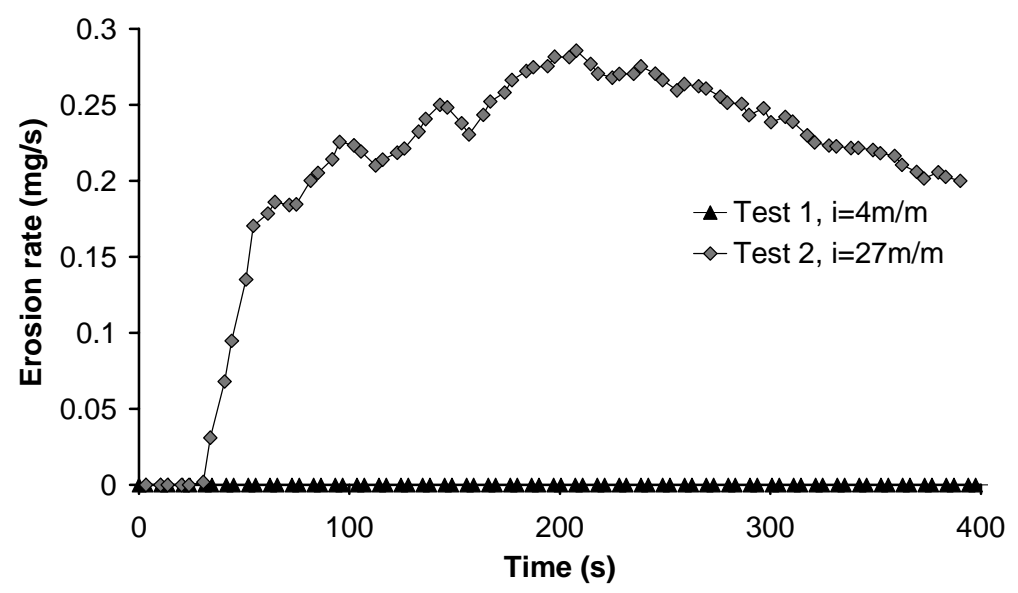

Figure 5. Erosion rate measured on $10 \%$ kaolin specimens using a $0.08 \mathrm{~mm}$ filter opening and for $i=4 \mathrm{~m} / \mathrm{m}$ and $i=27 \mathrm{~m} / \mathrm{m}$, respectively.

\section{Results}

\section{0\% Kaolin Specimens}

With a $0.08 \mathrm{~mm}$ filter opening size and a $4 \mathrm{~m} / \mathrm{m}$ applied hydraulic gradient (test 1 ), no significant internal erosion is observed. With a $27 \mathrm{~m} / \mathrm{m}$ hydraulic gradient (test 2), on the other hand, the migration of clay particles begins (Figure 5).

For a $4 \mathrm{~mm}$ filter opening, a $2 \mathrm{~m} / \mathrm{m}$ hydraulic gradient does not initiate any measurable migration of particles (test 3 ). When $i=4 \mathrm{~m} / \mathrm{m}$ (test 4 ), on the other hand, a continuous low migration of clay particles $(<0.1 \mathrm{mg} / \mathrm{s})$ is observed (Figure 6$)$. With a $4 \mathrm{~mm}$ filter opening, the critical hydraulic gradient is then approximately $4 \mathrm{~m} / \mathrm{m}$. When $i=8 \mathrm{~m} / \mathrm{m}$, the clay migration quickens until reaching $0.9 \mathrm{mg} / \mathrm{s}$. However, in this case, two successive phases are observed: first, a sharp increase of the erosion rate up to $0.9 \mathrm{mg} / \mathrm{s}$ at 70 seconds and then, a progressive decrease of the rate down to nearly zero between $70 \mathrm{~s}$ and $400 \mathrm{~s}$ (Figure 6).

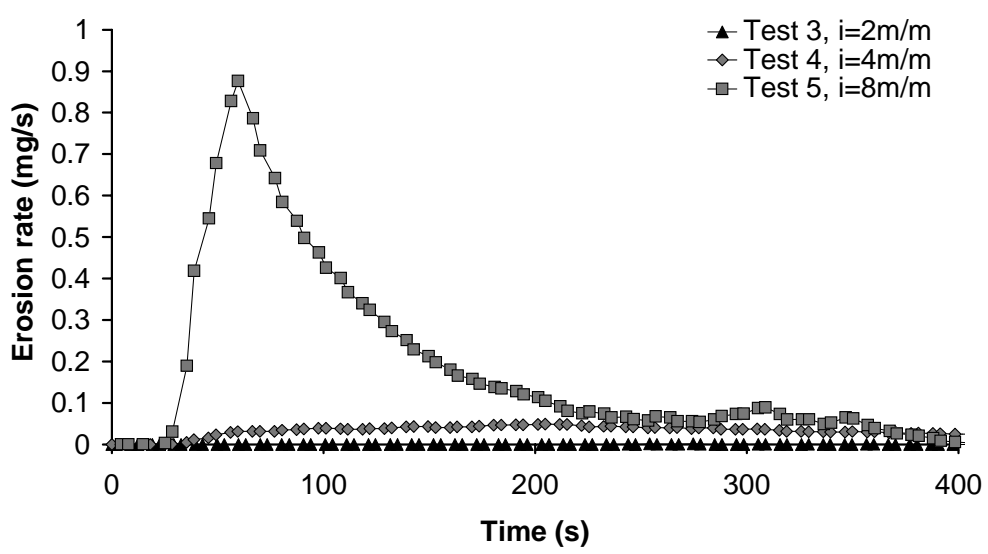

Figure 6. Erosion rate with a $4 \mathrm{~mm}$ filter opening and $10 \%$ kaolin specimens (low gradient). 


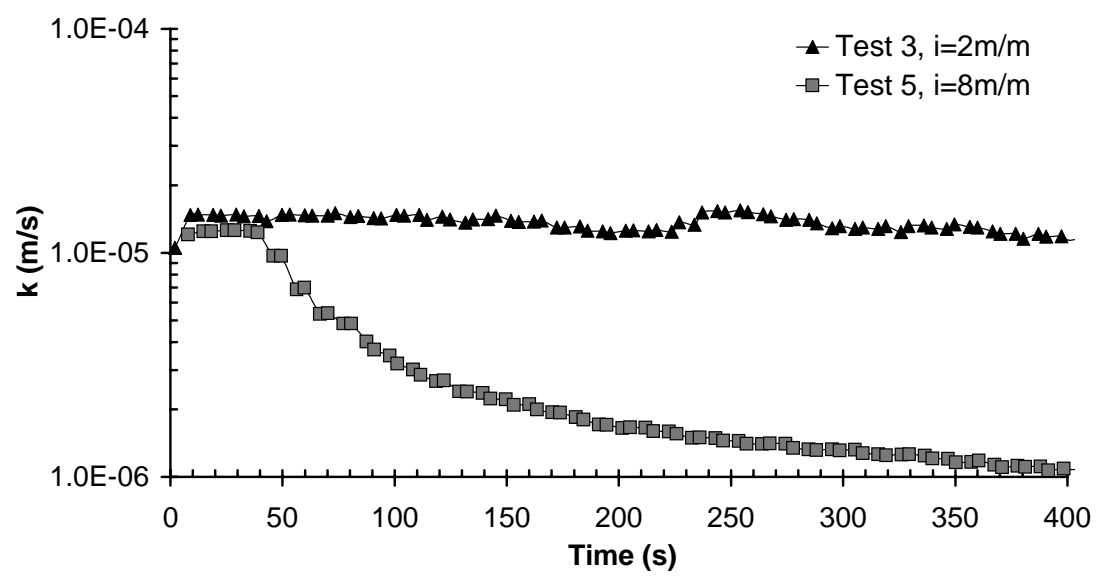

Figure 7. Conductivity versus time measured on $10 \%$ kaolin specimens using a $4 \mathrm{~mm}$ filter opening with $i=2 \mathrm{~m} / \mathrm{m}$ and $i=8 \mathrm{~m} / \mathrm{m}$.

The shape of the erosion rate vs. time curve suggests that the departure of some clay particles even at a low rate $(0.9 \mathrm{mg} / \mathrm{s})$ generates some structural changes within the tested specimens.

Thus, in order to examine the specimen hydraulic performances, we measure the evolution of the specimen hydraulic conductivity during the erosion tests with $i=2$ $\mathrm{m} / \mathrm{m}$ and $i=8 \mathrm{~m} / \mathrm{m}$. The Reynolds number, given by Equation 3, being lower than 4 $(R e=0.001$ in this case), the conductivity, $k$, can be calculated using Darcy's law:

$$
R e=v \frac{d_{50}}{v}
$$

where $v$ is the flow velocity $(\mathrm{m} / \mathrm{s}) ; d_{50}$, the grain mean diameter $(\mathrm{m})$ and $v$, the kinematic viscosity $\left(\mathrm{m}^{2} / \mathrm{s}\right)$.

For $i=2 \mathrm{~m} / \mathrm{m}$, the absence of migration agrees with the constant hydraulic conductivity measured. We note that the hydraulic conductivity of the $10 \%$ kaolin specimen $(k=1 \times$ $\left.10^{-5} \mathrm{~m} / \mathrm{s}\right)$ is higher than the $8 \%$ bentonite specimens $\left(2 \times 10^{-10} \mathrm{~m} / \mathrm{s}\right)$. For $i=8 \mathrm{~m} / \mathrm{m}$, the decrease of the erosion rate observed between $70 \mathrm{~s}$ and $400 \mathrm{~s}$ coincides with the decrease of $k$ from the initial $1.10^{-5} \mathrm{~m} / \mathrm{s}$ down to $1.10^{-6} \mathrm{~m} / \mathrm{s}$ (Figure 7 ).

With a hydraulic gradient of $27 \mathrm{~m} / \mathrm{m}$, the migration of particles is particularly intense and gives erosion rate values beyond the upper limit of the optical sensor $(6 \mathrm{mg} / \mathrm{s})$. The quantity of particles washed out from the specimen is then calculated by continuously weighing the effluents (Figure 8).

The mass versus time curves for 12, 22 and $27 \mathrm{~m} / \mathrm{m}$ hydraulic gradients present similar shapes, which reveal a mechanism of internal erosion in three successive stages:

- the first stage is characterized by an eroded mass nearly null;

- the second stage shows a sharp increase in the cumulated eroded mass;

- and in the third stage, the increase in the cumulated eroded mass is much smaller.

The discontinuity between each successive stage is indicated by break points. The break points between first and second stages are plotted on the graph time axis according to $i$ : $40 \mathrm{~s}, 170 \mathrm{~s}$ and $220 \mathrm{~s}$ for $27 \mathrm{~m} / \mathrm{m}, 22 \mathrm{~m} / \mathrm{m}$ and $12 \mathrm{~m} / \mathrm{m}$, respectively. They indicate a decrease in the erosion initial time as a function of the hydraulic gradient rise. The 


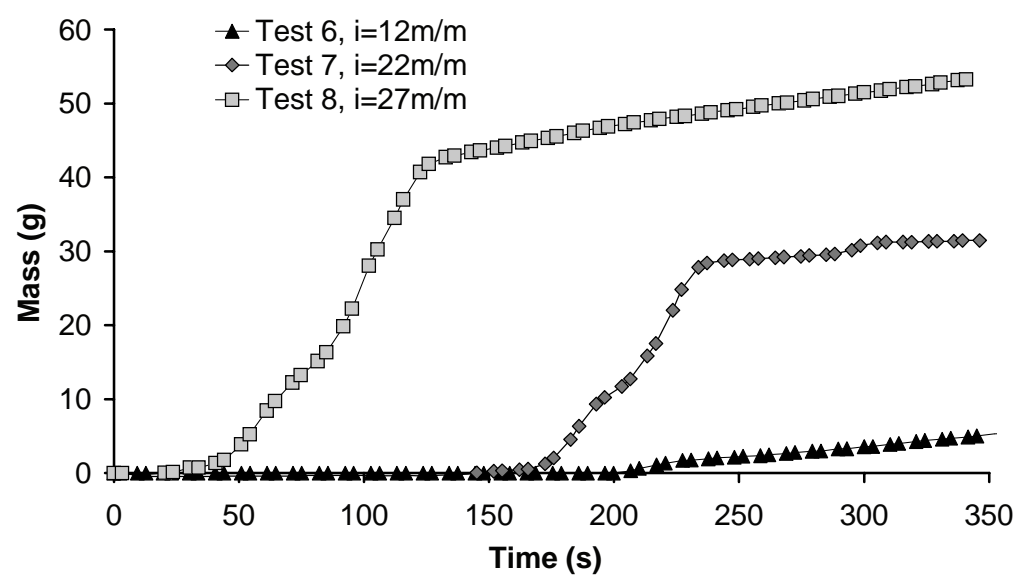

Figure 8. Cumulative mass of effluents measured during the 12,22 and $27 \mathrm{~m} / \mathrm{m}$ hydraulic gradient experiments on the $10 \%$ kaolin specimens with a $4 \mathrm{~mm}$ filter opening.

break points between second and third stages are easily identifiable on the 22 and $27 \mathrm{~m} / \mathrm{m}$ curves. The increase in the hydraulic gradient accelerates the phenomenon and increases the amount of eroded clay particles (Figure 8). The third stage is characterized by similar linear cumulative eroded masses within the range $0.02-0.05 \mathrm{~g} / \mathrm{s}$. The great quantity of eroded material measured during the $27 \mathrm{~m} / \mathrm{m}$ hydraulic gradient experiment signifies that the specimen progressively decreases in volume during the test. The shrinkage first appears at the bottom of the specimen (Figure 9b) and progresses upwards until the specimen fully collapses (Figure 9c).

\section{$30 \%$ Kaolin Specimens}

The tests are performed on the $30 \%$ kaolin specimens using some 0.08 and $4 \mathrm{~mm}$ filter openings, respectively. The quantity of clay particles eroded using the $0.08 \mathrm{~mm}$ filter opening is too small to be measured. Consequently, no internal erosion is observed in spite of high hydraulic gradients up to $110 \mathrm{~m} / \mathrm{m}$.

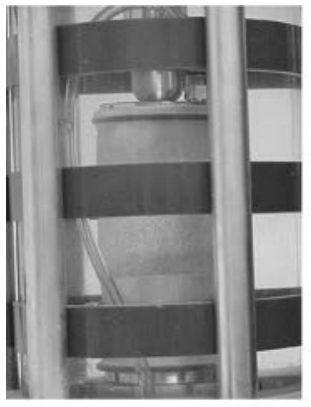

a) Before test

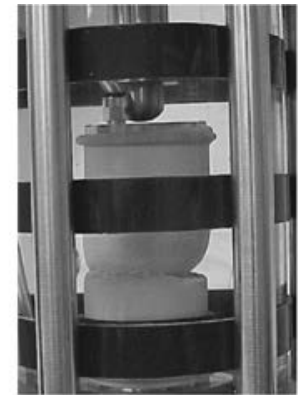

b) During test

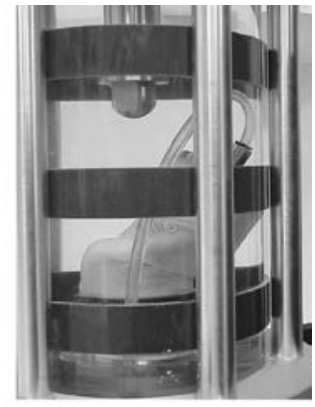

c) After test

Figure 9. Pictures of the specimen in the triaxial cell (test 8), a) specimen initial state; b) shrinkage of the specimen bottom during the erosion test $(i=27 \mathrm{~m} / \mathrm{m})$; c) specimen final collapse. 


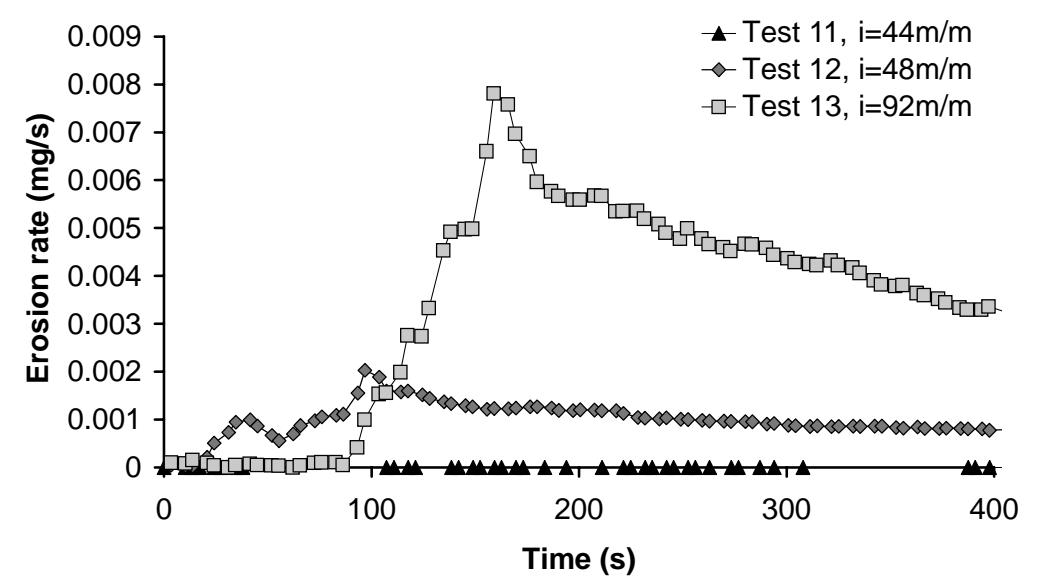

Figure 10. Erosion rates with a $4 \mathrm{~mm}$ filter opening and 30\% kaolin specimens for $i=44,48$ and $92 \mathrm{~m} / \mathrm{m}$, respectively.

With the $4 \mathrm{~mm}$ filter opening, on the other hand, variable and increasing erosion rates are measured according to the increasing hydraulic gradients (44, 48, $92 \mathrm{~m} / \mathrm{m}$ (Figure 10) and $168 \mathrm{~m} / \mathrm{m}$ (Figure 11)):

- no significant measurements (erosion rate $=0 \mathrm{mg} / \mathrm{s}$ ) when $i=44 \mathrm{~m} / \mathrm{m}$;

- maximum erosion rate of $0.002 \mathrm{mg} / \mathrm{s}$ when $i=48 \mathrm{~m} / \mathrm{m}$;

- maximum erosion rate of $0.008 \mathrm{mg} / \mathrm{s}$ when $i=92 \mathrm{~m} / \mathrm{m}$;

- maximum erosion rate of $4.6 \mathrm{mg} / \mathrm{s}$ when $i=168 \mathrm{~m} / \mathrm{m}$.

The 48 and $92 \mathrm{~m} / \mathrm{m}$ hydraulic gradient experiments display the same three stages already observed with the $10 \%$ kaolin specimens (first, nearly null eroded mass; then, a sharp increase in the eroded mass; and third, the eroded mass increases slightly.

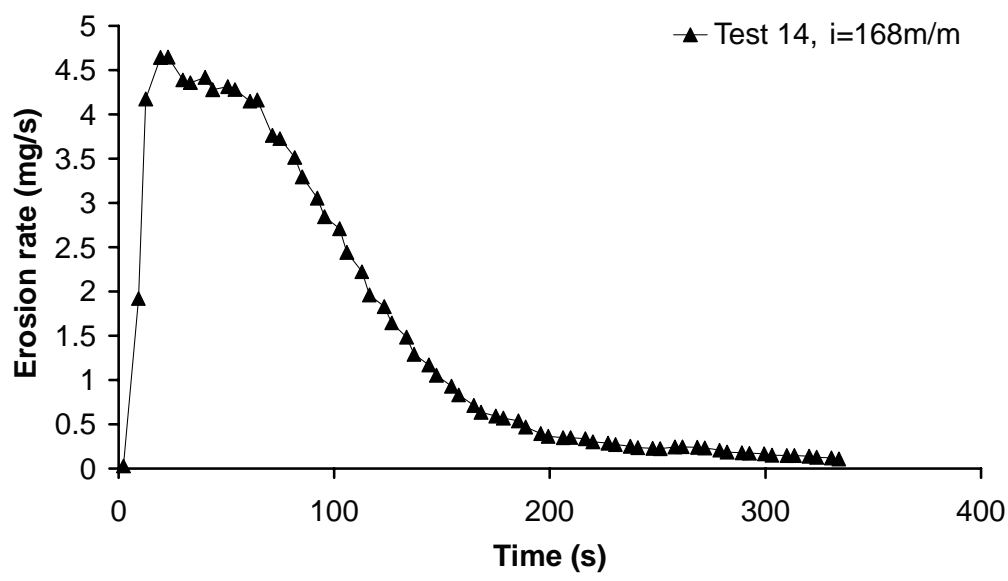

Figure 11. Erosion rate with $4 \mathrm{~mm}$ filter opening and 30\% kaolin specimens (very high hydraulic gradient). 
The test conducted with a $168 \mathrm{~m} / \mathrm{m}$ hydraulic gradient presents some very high erosion rates (up to $4.7 \mathrm{mg} / \mathrm{s}$ ) while, contrary to the other tests, we note the absence of the first stage (eroded mass nearly null).

\section{Discussion}

The test results present some extremely differing erosion rate values ranging from $q_{s}<1$ $\mu \mathrm{g} / \mathrm{s}$, for some tests, to $q_{s}>1 \mathrm{mg} / \mathrm{s}$, for some others. For most of the other tests, however, some moderate erosion rate values have been obtained. The clay content, here, seems to affect soil erodibility significantly. The results show that for a $10 \%$ kaolin specimen, the erosion rate is about seven times higher than for a $30 \%$ kaolin specimen. As the kaolin content increases, the initial conductivity decreases $\left(2.5 \times 10^{-5} \mathrm{~m} / \mathrm{s}\right.$ for a $10 \%$ of kaolin content and $1.5 \times 10^{-7} \mathrm{~m} / \mathrm{s}$ for a $30 \%$ ), causing the global flow within the specimens to be falling. The decrease in the particulate water velocity $v_{p}$ can be estimated as:

$$
v_{p}=\frac{v}{n}
$$

where $v$ is the flow velocity within the specimen $(\mathrm{m} / \mathrm{s})$ and $\mathrm{n}$, the porosity.

Darcy's law gives:

$$
v_{p}=\frac{k i}{n}
$$

For a given hydraulic gradient and two kaolin content values (10 and 30\%):

$$
i=c s t=\frac{v_{p 30 \%} n_{30 \%}}{k_{30 \%}}=\frac{v_{p 10 \%} n_{10 \%}}{k_{10 \%}}
$$

Therefore,

$$
v_{p 30 \%}=0.0066 v_{p 10 \%}
$$

with $n_{30 \%}=30 \%$ and $n_{10 \%}=33 \%, k_{30 \%}=1.5 \times 10^{-7} \mathrm{~m} / \mathrm{s}$ and $k_{10 \%}=2.5 \times 10^{-5} \mathrm{~m} / \mathrm{s}$.

This solution shows that the particulate velocity within sand/clay specimens with a $30 \%$ kaolin content is 150 times slower than with $10 \%$ kaolin specimens. When the velocity decreases, the strain generated by the flow within the samples also decreases and contributes to increase the internal erosion resistance.

For a $4 \mathrm{~mm}$ filter opening, the critical hydraulic gradient is $4 \mathrm{~m} / \mathrm{m}$ but with a $0.08 \mathrm{~mm}$ filter opening, it can be six or seven times higher. Consequently, the use of geotextile filters reduces particle erosion and the filter opening size is an important parameter to qualify the erosion rate in the same way as the hydraulic gradient.

For a hydraulic gradient slightly higher than the critical gradient (test 5), the erosion of a small amount of clay is accompanied by a decrease of ten times the conductivity of the same material, within which no eroded particle is detected (test 3). No significant volume change being observed, the conductivity decrease may be accounted for by some local porosity alterations due to the internal rearrangement of the clay particles. This phenomenon, characterized by some diffuse mass losses can be called suffusion and in our tests this suffusion is accompanied by a clogging in the specimen that induces a decreasing of conductivity. 


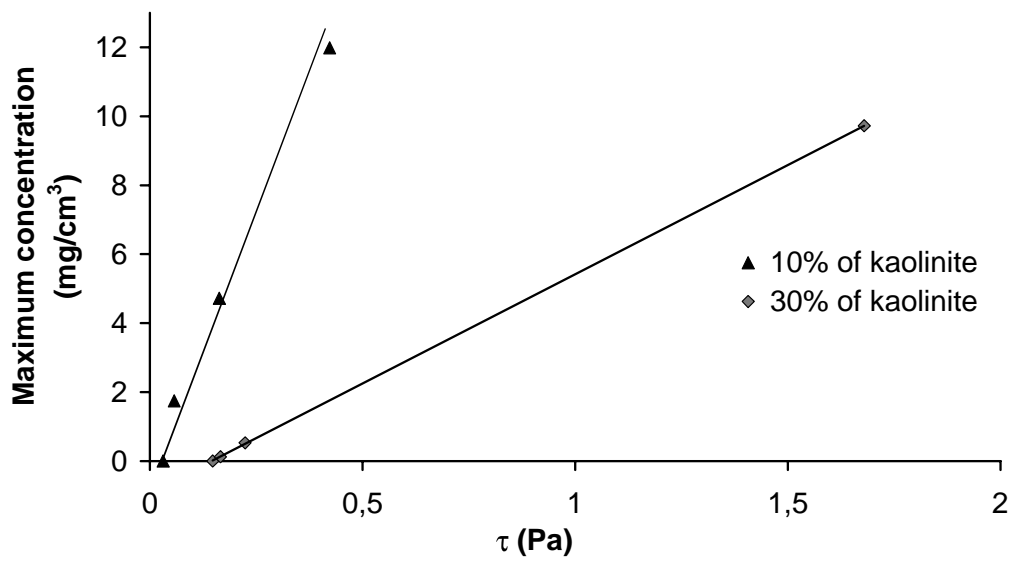

Figure 12. Maximum concentration versus hydraulic shear stress with a $4 \mathrm{~mm}$ filter opening.

For a high hydraulic gradient, the extensive particle migration generated causes some substantial volume changes at the bottom of the specimen, which finally collapses. This phenomenon is known as backward erosion.

These elements confirm Barakat (1991)'s results, which represent sand/clay samples as a double structure set: a primary structure, sand, and a secondary structure, clay. Subjected to a low hydraulic gradient, the secondary structure, only, is eroded without modifying the mechanical resistance. With a high hydraulic gradient, on the other hand, both the first and the secondary structures are altered, which causes the collapse.

With the intention of considering the three parameters (hydraulic gradient, conductivity and porosity), the hydraulic shear stress is calculated using Equation 1 for all the tests. The maximum solid content $\left(\mathrm{C}_{\max }\right)$ is the maximum value achieved during the tests.

From the results obtained, thanks to the specimens tested with hydraulic gradients between 2 and $168 \mathrm{~m} / \mathrm{m}$, it is possible to represent the maximum concentration versus the hydraulic shear stress. This representation is a linear function (Figure 12). The intersection of the linear curve with the hydraulic shear stress axis indicates the critical hydraulic shear stress $\left(\tau_{\mathrm{cr}}\right.$ ) (equal to $0.03 \mathrm{~Pa}$ and $0.15 \mathrm{~Pa}$ for $10 \%$ and $30 \%$ kaolin contents and a $4 \mathrm{~mm}$ pore filter, respectively).

The experimental data are satisfactorily fitted (4 points, correlation coefficient $\mathrm{R}^{2}=$ 0.99 ) by the linear function. However, some additional investigations are required to confirm the relationship between the concentration and the hydraulic shear stress.

\section{Conclusion}

The hydraulic conductivity can be strongly modified by internal erosion. The mechanisms responsible for the internal erosion are very evolutionary and depend on many parameters. In the face of such complexity, the internal erosion initiation and development criteria found in the literature are closely dependent on the studied structures and therefore diverse.

The experimental device described here can be used to saturate and consolidate reconstituted sand/clay specimens. The triaxial cells used for the parametric study have been modified to let the flow come through up to the core of the specimen.

The comparison of the first results achieved here with those obtained by Kenney et al. (1992) on sand/bentonite specimens demonstrates the good repeatability of the tests and 
validates the experimental procedure. Thanks to this device, the mechanisms that initiate internal erosion within sand/kaolin specimens have been examined. All the tests are carried out on sand/clay specimens with a $10 \%$ or $30 \%$ kaolin content, respectively, and with hydraulic gradients ranging between 2 and $168 \mathrm{~m} / \mathrm{m}$.

The value of the critical hydraulic gradient depends on the kaolin content. A hydraulic gradient higher than the critical value produces, first, a migration of the clay particles through a phenomenon of suffusion. This suffusion induces a clogging and finally the drop in the hydraulic conductivity by a factor of ten. If the hydraulic gradient keeps on increasing, the specimen structure is modified because the sand grains are transported by the phenomenon of backward erosion. Finally, the skeleton becomes unstable and the specimen collapses.

A high sand/clay ratio contributes to decrease the flow velocity within the specimen while increasing the internal erosion resistance. The use of geotextile filters also reduces particle transportation. For the same tested soil, the critical hydraulic gradient can be six or seven times higher with a $0.08 \mathrm{~mm}$ filter opening in comparison with a $4 \mathrm{~mm}$ filter opening.

For both tested clay percentages, the maximum effluent concentration is a linear function of the hydraulic shear stress.

To improve our understanding of these phenomena, we need additional information, which could be achieved by carrying out complementary tests to examine other sand/clay ratios and filter opening sizes. The experimental device potential can also be used to study the effects of the confining pressure on internal erosion kinetics. A preliminary calibration of the optical sensor to suit a larger range of clay minerals will also make it possible to study the influence of clay sensibility.

\section{References}

AFNOR (NF P 94-074). 1994. Essais à l'appareil triaxial de révolution. Association Française de Normalisation.

Arulanandan, K., and Perry, E.B. 1983. Erosion in relation to filter design criteria in earth dams. Journal of Geotechnical Engineering 109(5), 682-696.

Barakat, B. 1991. Instabilité aux écoulements des milieux granulaires, aspects morphologiques et probabilistes. Ph.D report, Ecole Centrale de Paris, France.

Bendahmane, F. 2005. Influence des interactions mécaniques eau-sol sur l'érosion interne. Ph.D report, Université de Nantes, France.

Kenney, T.C., and Lau, D. 1985. Internal stability of granular filters. Canadian Geotechnical Journal 22, 215-225.

Kenney, T.C., Van Veen, W.A., Swallow, M.A., and Sungaila, M.A. 1992. Hydraulic conductivity of compacted-sand mixtures. Canadian Geotechnical Journal 29, 364-374.

Khilar, K.C., Fogler, H.S., and Gray, D.H. 1985. Model for piping-plugging in earthen structures. Journal of Geotechnical Engineering 111(7), 833-846.

Monnet, A. 1998. Boulance, érosion interne, renard. Les instabilités sous écoulement. Revue Française de Géotechnique 82, 3-10.

Reddi, L.N., Lee, I., and Bonala, M.V.S. 2000. Comparison of internal and surface erosion using flow pump test on a sand-kaolin mixture. Geotechnical Testing Journal 23(1), 116-122.

Skempton, A.W., and Brogan, J.M. 1994. Experiments on piping in sandy gravels. Géotechnique 44(3), 440-460. 